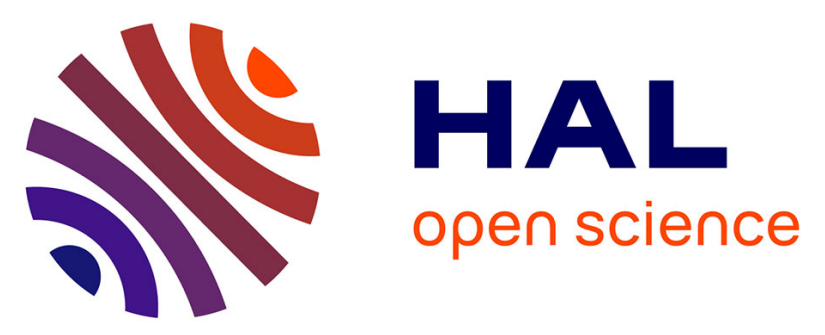

\title{
Analysis of flow measurements in the impeller and vaned diffuser of a centrifugal pump operating at part load.
}

\author{
Michel Toussaint, François Hureau
}

\section{To cite this version:}

Michel Toussaint, François Hureau. Analysis of flow measurements in the impeller and vaned diffuser of a centrifugal pump operating at part load.. 18th IAHR Symposium on Hydraulic Machinery and Cavitation., IAHR, Sep 1996, Valencia, Spain. hal-01294041

\section{HAL Id: hal-01294041 \\ https://hal.science/hal-01294041}

Submitted on 26 Mar 2016

HAL is a multi-disciplinary open access archive for the deposit and dissemination of scientific research documents, whether they are published or not. The documents may come from teaching and research institutions in France or abroad, or from public or private research centers.
L'archive ouverte pluridisciplinaire $\mathbf{H A L}$, est destinée au dépôt et à la diffusion de documents scientifiques de niveau recherche, publiés ou non, émanant des établissements d'enseignement et de recherche français ou étrangers, des laboratoires publics ou privés. 


\title{
Analysis of flow measurements in the impeller and vaned diffuser of a centrifugal pump operating at part load.
}

\author{
Michel TOUSSAINT \\ CNAM, Laboratoire de la chaire de Turbomachines, Paris. \\ François.HUREAU \\ CETIM, Laboratoire d'Hydraulique Industrielle, Nantes.
}

\begin{abstract}
In a recent european contract, four impellers with different specific speeds have been equiped with transparent front shrouds in order to obtain optical access to the flow between the blades. The presented results are the last analysis of internal flow measurements in one of these impellers (Ns32) fitted with a vaned diffuser. They are especially related with the interaction between impeller and diffuser, e.g. the phenomenon of flow separation, wakes, and backflow inside the pump. Unsteady velocity measurements were carried out in the hydraulic laboratory of CETIM with the help of laser doppler velocimetry technique. The data fields have been treated by the CNAM-LEMFI in order to give instantaneous view of the flow between the blades. From these pictures, a three dimensionnal movie has been built, that allows to explain some details in the behaviour of centrifugal impeller between $0.2 \mathrm{Qn}$ and $\mathrm{Qn}$.
\end{abstract}

\section{Introduction}

If a centrifugal pump operates under its nominal flow rate (Qn), there comes a moment when the "incoming flow" fails to fill simultaneously all the channels of the impeller thereby generating counterflows at the impeller inlet and outlet. The experimental results given in this paper show for example how the flow "swings" from the shroud side to the hub one when the flow rate is reduced, and where are located the backflow areas inside the channels of the impeller. The comparison of results between vaneless and vaned diffuses gives some explanation on the nature of separated flows in this part of a rotodynamic pump. These detailed flow measurements complete other experimental results achieved on centrifugal pumps in Europe $[2,3,4,11,12,13,14,18]$. They should be extensively used to calibrate the computational fluid dynamics. tools actually used in the design methodology of pump (see for exemple $[1,5,6,7,10]$ ). 


\section{Experimental setup.}

\subsection{TEST EQUIPMENT}

The test engine is a centrifugal pump which main characteristics at nominal point are: speed $1450 \mathrm{rpm}$, flowrate $136 \mathrm{l} / \mathrm{s}$, static head $30 \mathrm{~m}$, mechanical power $62 \mathrm{~kW}$. The flow at the outlet of the impeller is drived in a main collector linked to the pipe with 4 branch'lines. This configuration give an axisymetric behaviour of the flow within the pump, in the case of vaneless diffuser. The geometrical data of the centrifugal impeller ( 6 blades) and the vaned diffuser ( 8 blades) are given on figures 1 and 2, with the locations of velocity measurements. The test rig, that has been built to fulfill the different tasks for the investigations, is more completely described in reference [17].
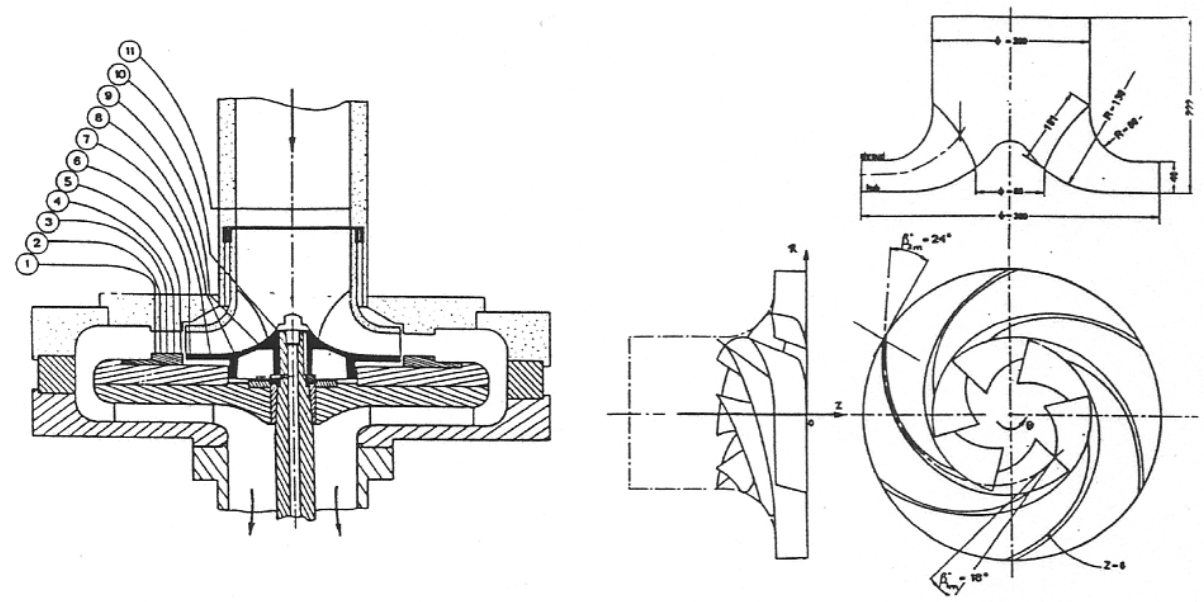

Figure 1. Test impeller (ns 32)
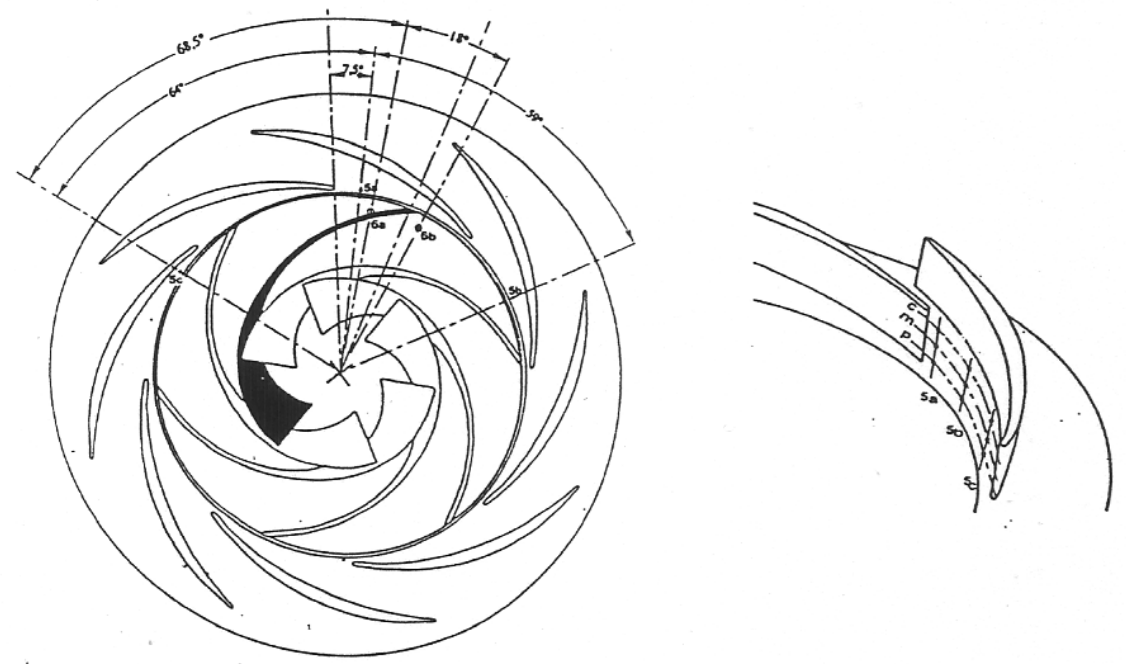

Figure 2. Vaned diffuser 


\subsection{INSTRUMENTATION.}

In addition to conventional apparatus such as a test bed (rotational speed, torque, delivery rate, etc.), the equipment includes a slip ring collector allowing the measurement of pressure provided by built-in seńsors. The scale model is also equiped to measure pressure fluctuations upstream and downstream from the impeller. The upper part of the model and the impeller flange are made of perspex to enable observation of any pre-rotation, recirculation or cavitation phenomena. Eleven glass ports, laid out as shown in Figure 1, provide access to impeller velocity measurements using the laser velocity measurement technique. Very fine particles (1 to $10 \mu \mathrm{m}$ ) of titanium dioxide act as tracers within the flow. The system used is a Doppler laser velocimeter with two interference fringe networks, including a COHERENT Argon laser source (6W output for all lines) and a TSI optoelectronic unit. Each reading of the two velocity components of these particles simultaneously leads to the input of the impeller's angle position using an optical encoder.

\section{Analysis of experimental results.}

\subsection{RECIRCULATION IN THE IMPELLER.}

The recirculation phenomena affecting the impeller and the diffuser in a plain diffuser type pump are summarised in the two drawings in Figure 3. It is noticeable that at delivery rates of between $\mathrm{Qn}$ and $0.61 \mathrm{Qn}$, slight signs of recirculation occur simultaneously in proximity to the impeller inlet and inside the diffuser. When the rate decreases, recirculation continues to spread, occurring in both the inlet and outlet of the impeller and much of the plain diffuser at very low delivery rates. Recirculation affecting the inlet originates at some distance in the impeller pipe. It takes up approximately $50 \%$ of the channel height and remains localised along the inner surface of the blade. This pocket of recirculation seems to "wear itself out" as it travels against the flow to reach the impeller outlet, which is logical since part of the recirculating fluid must be carried along as a result of the viscosity and set back on the right course by the "normal" delivery flow. These various observations confirm that recirculation at the impeller inlet is completely independent of the recirculation observed at the impeller outlet. 


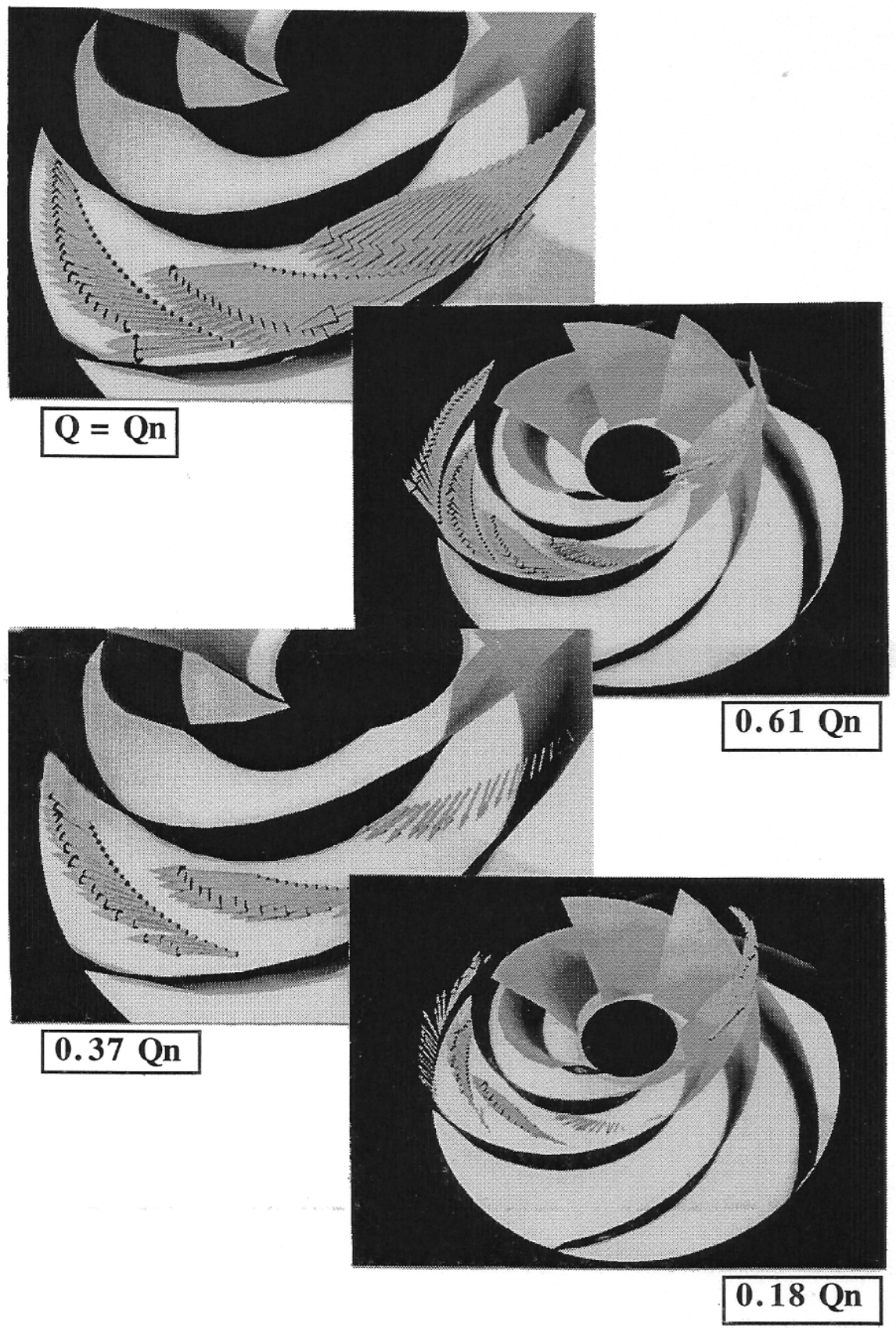

Figure 3: Flow measurements in the impeller. 


\subsection{INFLUENCE OF THE VANED DIFFUSER.}

Although it is true that the relative flow in a centrifugal impeller may be "almost steady" [15] [16], this is not the case in an industrial operation where the impeller is always followed by a diffuser, return pipe or volute. The interaction between the fixed parts (diffuser vanes or volute tongue) and moving parts usually leads to a turbulent flow that is unsteady in both a Galilean referential system and in an impeller-linked relative reference system. Research carried out into this type of flow [8] [9] makes analysis of the results difficult (it is always somewhat specious), since the subsequent processing of pinpoint measurements of velocity and pressure values in the channels between the vanes of a turbomachine impeller always requires the use of extensive computer and graphics facilities. Using 3D images we shall, in this article, present an analysis of the flow in the area of interaction between impeller and diffuser, in a centrifugal pump operating with a vaned diffuser.

A comparison of the various velocity profiles recorded in the impeller in configurations with either plain or vaned diffuser shows that the vaned diffuser has an almost negligible influence on the flow in the inter-vane channels, except near the impeller outlet. Figure 4, which gives a comparison of the profiles recorded on axis 7 in the two operating configurations, confirms this initial analysis. As regards recirculation at the inlet and in the impeller, the presence of a vaned diffuser makes no notable difference compared to the system operating with a plain diffuser.
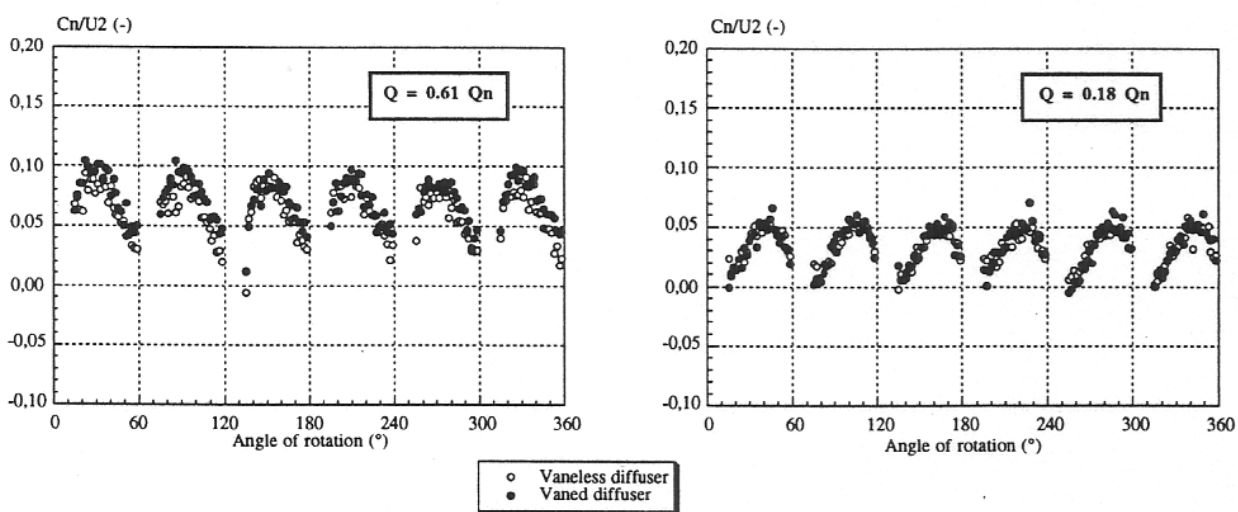

Figure 4 ; Comparison of velocity measurements with and without vaned diffuser. Axis 7 - $\mathrm{R}=0.75 \mathrm{R} 2$ - middle - $\mathrm{Cn}$ : normal to axis of measurement 
Near the diffuser inlet the influence is more important, especially at part load operation. The figure 6 gives at three flow rates the radial component of velocity on Axis 6 ( $R=0.92 \mathrm{R} 2$ ) with and without vaned diffuser. Taking into. account the disymetry of flow around the impeller, two locations of measurements on the same axis are given (6a and $6 b$; see on figure 2 )
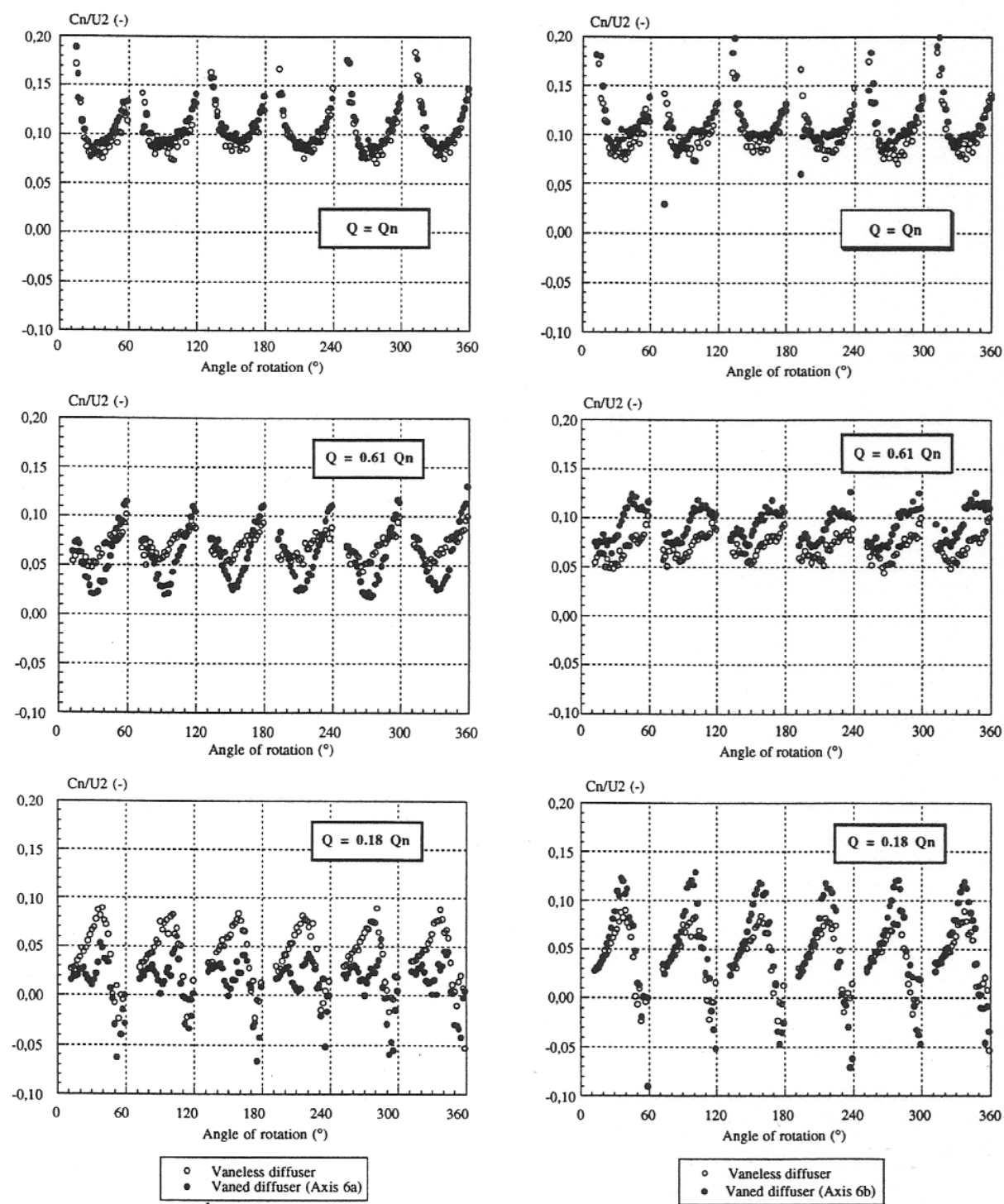

Figure 5: Comparison of velocity measurements with and without vaned diffuser. Axis 6 - $\mathrm{R}=0.92 \mathrm{R} 2$ - middle $(\mathrm{b} / \mathrm{b} 2=0.5)$ - left: axis $6 \mathrm{a}$; right: Axis $6 \mathrm{~b}$ 
The three-dimensional and unsteady phenomena which occur when the impeller vanes pass in front of the diffuser vanes may be given in vector form. This operation was carried out with support of the LEMFI Laboratory in Orsay using IRIS Explorer software on a Silicon Graphics workstation. An animated film was built using these $3 \mathrm{D}$ images.

The film explains the following phenomena in particular:

- at the nominal rate and slightly below (up to 0.9 Qn), the flow is particularly "stable" in the area around the diffuser inlet. The velocity deviations are small over a period of time and distribution is almost uniform between the diffuser vanes.

- at $0.82 \mathrm{Qn}$, separation occurs in the corner between the bottom of the vane and the concave side of the diffuser vane. This separation is resorbed as the impeller vane approaches and creates a flow running into this area.

- at $0.61 \mathrm{Qn}$, separation occurs on the shroud side (top of the diffuser vane). This separation is located between the leading edge of the vane and the upper flange and it acts as a result of the significant wake generated at the impeller outlet at this flow rate. - at 0.37 Qn, the separation again occurs at the bottom of the diffuser vane, owing to recirculation inside the impeller which completely alters the axial profile of the velocity field.

- at $0.18 \mathrm{Qn}$, the separation phenomenon at the leading edge of the diffuser vane is further accentuated. It occupies the full height of the blading when an impeller vane passes in front of the diffuser vane.

This analysis of the flow between the rotor and stator highlights the two main characteristics of the unsteadiness inside a pump (see ref [1]):

- potential interaction: this corresponds to the encounter between 2 distinct flows. Even in the case of an inviscid flow, a spiral flow passing in front of a flow between fixed channels leads to periodical fluctuations in local velocity values.

- wakes interaction: because of the viscosity of the water, separation arises in the impeller and generates a backwash in the outlet along the concave side of the vanes. The density of the wake varies depending on the pump operating condition. The wake reaches the diffuser vanes and creates further periodic local disturbances.

In this type of machine it may be assumed that the two types of interaction are of similar size. Both phenomena are superposed giving rise to considerable fluctuations in velocity, mainly near the leading edge of the diffuser vanes. These local hydrodynamic disturbances spread further along the flow and cause loud noises, mainly due to acoustic propagation. 


\section{Conclusions}

An analysis of the test results obtained for a centrifugal impeller with or without vaned diffuser has enabled us to emphasise the following points.

* The phenomenon of the recirculation beginning inside the impeller leads to complete instability of the flow between the vanes and causes a significant increase in the overall level of velocity fluctuation. The three-dimensional aspect becomes predominant and everything occurs as if the relative flow in the impeller formed an eddy as a result of the effect of the various curvatures of the sides. Separation appears on the concave side of the vane near the front flange where the radius of curvature is the smallest. At the impeller outlet, the recirculation phenomena in the impeller is superimposed on the separation phenomena affecting the vaneless diffuser, and this complicate analysis at this particular spot. Reverse flows in the impeller are only visible at a very low flow rate (near the trailing edge they appear on the outer surface of the vanes) whereas at or near the nominal rate recirculation can already be observed in the diffuser.

* By comparison, the measurements taken with a vaned diffuser show that the recuperating part at the impeller outlet has very little effect on the flow inside. The area near the leading edge of a diffuser vane is the region where the flow is most disturbed when the rate decreases, in both the impeller and the diffuser. In particular, when the rate reaches the critical recirculation value in the impeller, it is observed that the profiles suddenly fail to match the delivery flow.

This study marks an end to the analysis of periodic flow in the ns 32 impeller. All the results obtained will serve as a database for the definition of computation codes. Work on the subject is currently being carried out by the SHF's Turbomachine Working Group - Internal flows and related performances. Furthermore, the turbulent aspect of the velocity field may be dealt with in the course of further research work.

\section{References}

1. BERT P.F., COMBES J.F., KUENY J.L. (1996) Unsteady flow calculation in a centrifugal pump using a finite element method, XVIII IAHR Symposium on Hydraulic Machinery and cavitation, Valencia, Sep. 16-19.

2. BOIS G., RIEUTORD E. (1990) Etude de l'écoulement en sortie de roue de pompe centrifuge depuis le débit nominal jusqu'au débit critique de recirculation, Compte rendu MRT n 88 H 0636, Octobre 1990.

3. CAIGNAERT G., BARRAND J.P. (1989) Débits critiques de recirculation: synthèse de l'ensemble des résultats expérimentaux sur les roues SHF essayées en air (ENSAM Lille) et en eau (INSA Lyon, EPF Lausanne, Hydroart Milan) 20èmes journées de l'Hydraulique, SHF Lyon, 4-6 Avril.

4. CASEY M.V., EISELE K., ZHANG Z., GULICH J., SCHACHENMANN A. (1995) Flow analysis in a pump diffuser, part 1: LDA and PTV measurements of the unsteady flow, ASME Paper, FED Summer Meeting, Symposium on Laser Anemometry. 
5. CASEY M.V., EISELE K., MUGGLI F.A.., GULICH J., SCHACHENMANN A. (1995) Flow analysis in a pump diffuser, part 2: Validation of a CFD Code for steady flow, ASME, Numerical simulations in turbomachinery, Vol.227 pp.135-143

6. COMBES J.F., GRIMBERT I., RIEUTORD E. (1991) An analysis of the viscous flow in a centrifugal pump with a finite element code, Fluid Machinery Forum, 1st ASME-JSME Fluids Engineering Conference, Portland, Oregon, June 23-27.

7. CROBA D. (1993) Modélisation de l'écoulement instationnaire dans les pompes centrifuges. Interaction roue et volute, Thèse Doctorat, INP Grenoble, Juillet 1993.

8. HUREAU F, KERMAREC J., FOUCHER D. (1993) Etude de l'écoulement instationnaire dans une pompe centrifuge fonctionnant à débit partiel, 1st International Symposium on Pump Noise and Vibrations, Clamart, France, July 7-9, pp.

9. HUREAU F., KERMAREC J., STOFFEL B., WEISS K. (1993)Study of internal recirculation in centrifugal impellers, ASME, 2nd Pumping Machinery Symposium, Washington, D.C, June 20-24, FED Vol. 154, pp. 151-157.

10. LONGATTE F. (1996) Analyse phénomènologique du couplage rotor-stator dans les pompes centrifuges. Etude sous Fluent d'une pompe 2D avec diffuseur aubé, LEGI-CREMHyG, Mai 1996.

11. MOREL Ph. (1993) Ecoulements décollés dans une roue de pompe centrifuge- Conception et réalisation d'un banc d'essai. Analyse des pressions pariétales, Thèse Doctorat, Université de Lille, Decembre 1993.

12. PAONE N., RIETHMULLER M.L., VAN DEN BRAEMBUSSCHE R.A. (1989) Experimental investigation of the flow in the vaneless diffuser of a centrifugal pump by particle image displacement velocimetry, Experiments in Fluids 7, Springer Verlag 1989, pp 371-378

13. STOFFEL B., WEISS K. (1994) Experimental investigations on part load phenomena in centrifugal pumps, World Pumps, October 1994, pp 46-50

14. STOFFEL B., LUDWIG G., WEISS K. (1992) Experimental investigations on the strucure of part-load recirculations in centrifugal pump impellers and the role of different influences, XVIth IAHR Symposium, Sao Paulo, Brazil, September 14-18.

15. TOUSSAINT M. (1993) Contribution à l'étude des recirculations dans les pompes rotodynamiques. Thèse de doctorat, Université P et M Curie Paris VI, Paris, Décembre 1993.

16. TOUSSAINT M. (1994) Etude des recirculations dans les pompes centrifuges roue Ns 32 diffuseur lisse, Rapport interne CNAM/CETIM, Paris, Septembre 1994.

17. TOUSSAINT M., HUREAU F. (1993) Etude expérimentale de l'écoulement instationnaire dans une pompe centrifuge fonctionnant à débit partiel, IAHR, 6th International Meeting, The behavior of Hydraulic Machinery under steady oscillatory conditions, Lausanne, Sept. 1993.

18. UBALDI M., ZUNINO P., BARIGOZZI G., CATTANEI A. (1994) An experimental investigation of stator induced unsteadiness of centrifugal impeller outflow, ASME, La Haye, Paper 94-GT-105. 